\title{
Postmodern Bir Film Anlatısı: Kayıp Otoban (Lost Highway)
}

\author{
Ali ÖZTÜRK ${ }^{1}$ \\ ${ }^{1}$ Asst., Prof. Dr., İstanbul Ayvansaray University, Faculty of Fine Arts, Design and Architecture, Deparment of \\ Radio, Television and Cinema, İstanbul, Turkey
}

Geliş Tarihi/Received: 22.01.2020

Kabul Tarihi/Accepted: 18.02.2020
Doi: doi.org/10.31200/makuubd.678945

Araştırma Makalesi/Research Article

\section{ÖZET}

Sanat dallarından mimari, edebiyat ve sinema başta olmak üzere birçok alanda kendisini hissettirten postmodernizm, batı medeniyetini sürükleyen politik tepki hareketlerinin bir yansıması olarak bilinir. Genel anlamda yeni bir kültürel olgu olarak, modernizme karşı oluşan bir tepki hareketi olarak nitelendirilebilir. Ancak her ne kadar modernizmin tekliğine karşı var olmuş bir olgu olarak görülse de postmodernist kuramcılarından olan Foucault ve Lyotard'a göre, estetik anlatının günlük hayat pratiklerine karışması sonucu oluşan bir yaklaşımdır.

Eklektik bir anlatı yapısına sahip olan postmodernizim, her türlü sanatsal anlayışı irdeleyip kullanabilme potansiyelini bünyesinde taşır. Bu yapısıyla hikâye aktarımında iç içe geçmiş örgüsel olay akışı üzerinden ilerler. Ancak film anlatısında kullanılan bu yöntem, izleyicinin filmi anlamlandırmasını zorlaştırabilmektedir. $\mathrm{Bu}$ zorluğun temelinde ise olay örgüsünde yaratılmış olan alt ve üst katmanlar arasındaki bağlantıyı anlamlandıramamasından kaynaklanmaktadır.

Bu çalışmanın amacı postmodern anlatı örneklerinden olan Kayıp Otoban (Lost Highway 1997) filminin türün özelliklerini yansıtıp yansıtmadığını üzerinde bir analiz yapmaktır. Ancak bu analizi postmodern sinemanın özelliklerinden olan pastiş, parodi ya da ironi üzerinden yapılmayacaktır. Bunun nedeni David Lynch'in olay aktarımında gerçeklik ve kurgu yoluyla aktarımını yaparken aynı zamanda gerçek ve gerçekdışılık arasındaki ayrımın bulanıklaştırmasıdır.

Anahtar kelimeler: Postmodernizm, Postmodern Sinema, Kayıp Otoban, David Lyinch. 


\section{A Postmodern Film Narrative: Lost Highway}

\section{ABSTRACT}

Postmodernism, which makes itself felt in many fields of art, especially architecture, literature and cinema, is known as a reflection of the political reaction movements that have driven Western civilization. In general, postmodernism is referred to as a reaction to modernism as a new cultural phenomenon. However, although Postmodernism is said to be a phenomenon that has existed against the uniqueness of modernism, according to Foucault and Lyotard, one of the postmodernist theorists, it is the result of interfering aesthetic narrative with daily life practices. Postmodernism, which has an eclectic narrative structure, has the potential to examine and use any artistic understanding. With this approach, the story proceeds through the nested mesh event transfer. This method used in film narrative may make it difficult for the viewer to make sense of the film. This is due to the difficulty of the audience in establishing the connection created between the lower and upper layers created in the plot.

The aim of this study is to analyze whether the film Lost Highway (1997), one of the postmodern narrative examples, reflects the characteristics of the genre. However, this analysis will not be based on pastiche, parody or irony, which is one of the characteristics of postmodern cinema. The reason for this is that while David Lynch transmits through reality and fiction in the transfer of events, it does not blur the distinction between real and unreal.

Keywords: Postmodernism, Postmodern Cinema, Lost Highway, David Lyinch.

\section{GIRIŞ}

Rönesans’tan sonrası ortaya çıkan modernizm, yeni olanı elde etmeye yönelik bir üretim aşamasını getirmekle birlikte, bilimselliği öne çıkaran bir kültürün de ifadesidir. Bilimin sağladığı kazanımlarla insanlığın refaha ulaşabileceğini ileri süren ve 19. yüzyılın sonlarında ortaya çıkan modernizm, kendine özgü sanat aktarımlarıyla öne çıkmıştır. Modernizm sanayileşen toplumun estetiğinin ifadesi olduğunu belirten Lyotard'a göre bu anlayış doğrultusunda üretilen sanat eserinde önemli olan şey, özgün olma ve bireyselliktir (Lyotard, 2014: 156).

Modernist anlayışa karşı sert bir tavır sergileyen postmodernizm ise bünyesinde eklektik bir yapıyı bulundurur. Bu yapı, özgün ve belli bir üsluba sahip olma gibi seçkinci nitelikleri olmayan kuralsız bir yapı anlayışıyla aktarımlarını yapar. Bu aktarım anlayışla oluşturulan eserlerde sanatın metalaşması, sürekli yenilikçilik, geçmişin reddi gibi konularına 
yönelik eleştirel bir tavır geliştirir. Giddens'a göre postmodernizmin bu tavrı yiten, kaybolan değerleri taşıyan, standartlaşmış yaşam biçimlerine eleştirel bir bakıştır (Giddens, 1998: 28). Bu konuda Best ve Kellner da benzer bir duruş sergilemektedir. Postmodernizm çeşitli sanatsal biçimlerindeki modernist üslubu red ederek, daha eski modern biçimler üzerinde tahakküm kuran, yeni bilinç ve tecrübe biçimleri yaratan genç kapitalist toplumun kültürel egemenliği olduğunu belirten Best ve Kellner'a göre postmodernist sanat, herhangi bir ilkeye bağl1 kalmaksızın sanat eserini oluşturan bir anlayışın ifadesidir (Best ve Kellner, 1998: 223- 224).

Modern sanat anlayışında önemsenen özgün olma, öncülük etme, yenilik ve soyut gibi kavramları, postmodern sanat anlayışta karşılık bulmamış, bunun yerine nostalji, pastiş, eklektizm, figür, yüzeysellik ve parçalılık gibi unsurlar kabul görmüştür. Lyotard'a göre bu yaklaşımın temelinde sanat anlayışındaki çoğulculuktan kaynaklanmaktadır. Ancak bu çoğulcu yapısına rağmen uygun formların temsili ile imkânsız olanın nostaljisinin birlikte yaşam beğeni anlayışını reddeder (Lyotard, 1990: 57-58). Başka bir ifadeyle sanat anlayışında modern ve modern öncesinin gerçekçi, nesnel temsil tekniklerine dönebilmekle birlikte, eski olan sanatı yeniden canlandırma amacı taşımamaktadır.

Toplumsal yapıdaki hareketlerden ortaya çıkan Postmodernizm 1970'li yılların sonlarında başlayarak zaman içerisinden artan bir biçimde sinema anlatı dilinde etkili hale gelmiştir. Küreselleşme olgusu ile birlikte kültürel formların esnek ve akışkan, çoklu bir yapıya doğru evrilmesi postmodern düşünceyi tanımlayan unsurlar sinemada sinemada bu dönemde kendisini hissettirmeye başlamıştır (Urry, 1999: 39-40).

1990’lı yıllarla birlikte bu süreç hızlanmış (Smith, 2003) ve sinemada postmodern anlatının kullanılmaya başlanması, sadece film anlatı dilinin değişimini değil, aynı zamanda gerek toplumsal ve gerekse de politik hayattaki değişimlerin film içeriklerine aktarımını da getirmiştir. Özellikle bu dönem ile birlikte sinemada gerçeklik, bellek yitimi, ya da fantezi evreni arasındaki sınırların şeffaflaşması, filmsel gerçekliğin farklı biçimlerde aktarılabiliyor olması bu yönde film sayısının artmasına neden olmuştur.

Sinema anlatı dilinde yarattığı çoklu ve parçalanmışlık yapısı, film karakterlerinin gerçekliklerinin farklılaşması, parçalanması ve bunun sonucunda da karışık bir ruh haline girmesi, farklı kimlikler ve dünyaların karışmasına yol açmıştır. Bu dönemde çekilen postmodern filmlere örnek olarak başta çalışma konusu olan yönetmenliğini David Lynch'in yaptığı Kayıp Otoban (Lost Highway 1997) olmak üzere Quentin Tarantino filmler, Christopher Nolan'ın 2000 yılında çektiği Memento, James Mangold'un Kimlik (Identity 2003) Brad 
Anderson'ın yönetmenliğini yaptı̆̆ı Makinist, (The Machinist 2004) filmleri verilebilir. Bu filmlerin ortak özellikleri gerek mekân ve gerekse de zaman kavramına ilişkin bütünlük algısının parçalanmasıdır. Sennett, bu durumu zaman ve mekân algısının parçalara ayrılması ya da yeniden yaratılma süreci olarak tarif etmektedir (Sennett, 2019: 40-42).

$\mathrm{Bu}$ çalışmada kendine özgü anlatım diliyle, zaman ve mekâna ilişkin film karakterlerinin çevrelenen gerçeklerini farklı bir bakış açısıyla sunan David Lynch'in 1997 yılında çektiği Kayıp Otoban (Lost Highway) filmi incelenmiştir. Bu inceleme kapsamında film, parçalanmış gerçeklik ve kimlik, bellek kaybı, şizofreni, mekân ve zaman algısında sürekliliğin ve doğrusallığın yitirilişi gibi postmodernist sinema anlayışı bağlamında değerlendirilmiştir. Ancak bu analizi postmodern sinemanın özelliklerinden olan pastiş ya da ironi üzerinden yapılmamaktadır. Bunun nedeni David Lynch'in gerçeklik ve kurgu yoluyla olay aktarımını yaparken aynı zamanda gerçek ve gerçekdışılık arasındaki ayrımın bulanıklaştırmasıdır. Lynch, ilk olarak olay örgüsü aktarımında gerçek ile kurgu arasında bir fark olabileceğine yönelik bir algı oluşturduktan sonra, ikinci olarak görüneni olayın dışında bırakarak neyin gerçek ve neyin yanılsama olduğuna ilişkin belirsizliği üzerinden anlatısını kurmaktadir.

\section{POSTMODERNIZMI OLUŞTURAN YAPI}

Kavram olarak postmodernizm ilk olarak bakıldığında modernizemden sonra düşünsel oluşumun geldiğini gösteriyor olsa da gerçek anlamda tanımlanması zor bir kavramdır. Kelime olarak "post”"un modern olandan farklı bir dönemin işareti olarak mı, yoksa düşünsel yapıda modernizemden kopmayı mı göstermektedir. Bu konuyla ilgili farklı görüşlerin olduğu söylenebilir. Bununla birlikte bazı düşünürler böyle bir yaklaşımı kabul etmemekte yâda bu durumu bir süreklilik ilişkisi içerisinde ele almak eğilimindedirler. $\mathrm{Bu}$ iki yaklaşım çerçevesinde bakıldığında, postmodernizmin kavramlaştırılmasının ilk olarak Federico de Onis tarafindan 1930'lu yıllarda modernizme karşı ortaya konulan bir tepkiyi aktarmak için kullanılmış olduğu görülmektedir. Ancak 1960’lı yıllarda Rauschenberg, Cge, Fiedler Buroughs ve Hassan gibi eleştirmenler tarafindan akademilerde kurumlaşmış olan "tükenmiş yüksek modernizmin ötesinde yer almak” düşüncesi üzerinden kullanılmıştır. 1970 ve 1980'li yıllarda ise başta mimaride olmak üzere, görsel sanatlarda sanatın birçok alanında gittikçe yaygınlaşan bir kavram olarak kullanılmıştır (Featherstone, 1996: 27-28). Ancak postmodernizm kavramı Lyotard, Vattimo, Derrida, Foucault, Habermas, Baudrillard ve 
Jameson gibi teorisyenin çalışmalarıyla birlikte felsefi bir söyleme dönüşmüştür (Bertens, 1995: 111).

Postmodernizmin ortaya çıkışında modernizmde yaşanan başarısızlıkların etkili olduğu söylenebilir. Bu başarısızlığın nedeni, 20 yüzyıl yaşanan iki dünya savaşı, sosyalizm ve faşizm gibi totaliter rejimlerin ortaya çıkışı, sömürgecilik girişimlerine ve araçsal rasyonalizm gibi gelişmelerdir. Yaşanan tüm bu gelişmeler modernizmin mutlu bir geleceğe yönelik öngörüsünü kuşkulu hale getirmiştir. Oluşan bu kuşku başta sanat ve felsefe olmak üzere farklı alanlara yansımıştır. Modernizmin hayal kırıklığı yaratması, ideallerinin zafiyet göstermesiyle birlikte, farklı disiplinlerin pozitif bilgiye bakışı olumsuz yönde etkilenmiştir (Brown, 1995: 2-3). Gelner'a göre postmodernizm yapısalcılıktan sonra ortaya çıkan bir felsefedir. Bu felsefenin yöntemi ve okuma tarzlarını ise Amerikan akademik dünyasındaki yansımaları ve daha çok çağdaş düşüncenin bilişsel temellerinin sorgulamasıdır. David Ashley de Gelner gibi postmodernizmi yapısalcılık sonrası felsefeye ilişkilendirerek aktarmaktadır. Ona göre postmodernizm olarak nitelendirilen felsefe, Durkheim'in yapısalcılığının başarıya ulaşamamasına yönelik postyapısalcı reaksiyonun aydınlar üzerindeki etkisi ile anlaşılabilir (Ashley, 1997: 34). Jean Wahl'in postmodernizme yaklaşımı ise varoluş felsefesi üzerinedir. Ona göre felsefenin amacı değişmez gerçeği bulup onu yansıtmak değil, insani eylemler ile hayatın anlamı arasındaki ilişkiyi değerlendirmektir (Murphy, 2000: 35).

Modernizme yönelik yapılan eleştirilerin odağında da modern felsefenin yaşam karşıtı bir karaktere bürünüp, varoluşu görmemesi ya da görmezden gelmesidir. Vattimo’nun, postmodernizme yönelik yaklaşımı daha çok Nietzsche ve Heideggar'in felsefeye bakışları ürerinden ilerletmektedir. Ona göre modernliği bilimsel bilginin, postmodernliği ise enformasyon teknolojilerinin karakterize etmektedir. Modernizmden postmoderne geçişi mitlerden arındılılması olarak gören Vattimo, bu geçişi felsefi formunu Nietzsche'nin felsefik düşüncesinde bulduğunu belirtmektedir (Vattimo, 1992: 41-42).

Postmodern felsefesinin önemli temsilcilerinden olan Baudrillard gerek Marksizmi ve gerekse de yapısalcılığı sert bir biçimde eleştirmektedir. Ona göre içinde yaşadığımız dönemin klasik teorilerinin önemini yitirdiğini; modeller, kodlar. Enformosyon ve medya yoluyla gerçeğin yerini taklitler aldığını, gerçek olanla taklit arasındaki ayırımın kalmamıştır (Sim, 1999: 11). Reklam ve televizyonun kamusal alan ile özel alanı parçaladığını belirten Baudrillard, bunun sonucunda postmodern dönemde toplumsalın da sonunun geldiğini belirtmektedir. Buda tahrip edilmiş olan moderniteden geriye kalanlar ile oynanan bir oyundan 
ibarettir (Bertens, 1995: 277-278). Baudrillard 'a benzer bir yaklaşım da Foucault dile getirmektedir. Foucault, iktidarın karmaşık ve çoğul bir karaktere sahip olduğunu, postmodern dönemde bunun tamamen soyut bir hale geldiğini belirtmektedir (Best ve Kellner, 1998: 153).

Postmodernizmi dönemsel bir kavram olarak değerlendiren Jameson, postmodernizmin kapitalizmin gelişme mantığı içerisindeki bir sürece denk geldiğini belirtmektedir. Bu dönemi pazar kapitalizmi, tekel kapitalzmi ve geç kapitalizm olarak üç ayrı evreye ayrılır. Her bir evre ise aynı bir kültürel görünüme sahip olup postmodernizm de geç kapitalizmin kültürel egemeni veya mantığıyla aynı anlama gelmektedir (Bertens, 1995: 162). Postmodernizmin biçimsel bir yap1 olmasından ziyada tarihsel bir kavram olduğunu belirten Jameson, girişiminin tarih içerisinde şimdilik zaman üzerine diyalektik girişim olduğunu belirtmektedir (Jameson, 1994: 161-162). Jameson, önceki kültürden radikal bir şekilde yaşanan kopuşun postmodern kültürün ortaya çıkışını 1950'lerin sonuna, başka bir ifadeyle elektronik ve nükleer güçle çalışan araçların üretilmiş olmasıyla ilişkilendirir (Dear, 1993: 102).

Şizofren kavramına yaklaşımı Lacan'ın bakış açısıyla ele alan Jameson, bu kavramı öznenin dil ve konuşma alanı içinde iktidar kurmadaki başarısızlığından kaynaklanan dilsel bir düzensizlik olarak ele alır. Bu doğrultuda postmodernizmi gerçeğin imajlar içinde zamanın şizofrenik parçalanışının daimî şimdi içinde bir dönüşümü olarak ifade eder (Bertans, 1995: 163). Böyle bir dönüşüm gerçekleştiği postmodernizmin en belirgin özelliği ise, derinliğin kaybı ve neden kavramının solmasıdır. Önemli postmodernist kuramcılardan olan Lyotard ise "Postmoden Durum" adlı çalışmasında, modern çağın meşrulaştırıcı söylemlerini ve bu doğrultuda oluşmuş olan felsefik düşünceleri eleştirmiştir. Lyotard, modern bilimin kendisini meşrulaştırmak için kullandığı söylemin felsefe olarak aktarıldığına dikkat çekmektedir (Appleby, 1996: 138). Lyodard'ın vurgulamaya çalıştığı husus, toplumların post endüstüriyel, kültürlerin de postmodern diye nitelenen çağa girmesiyle birlikte bilginin konumlandırıldığı yer konusunda önemli değişikliklerin oluştuğudur.

Frankfurt okulu içerisinde konumlandırılabilecek olan eleştirel teorinin önemli isimlerinden olan Habermas da postmodernizmin kavramlaştırılması konusunda eleştirel bir tavır sergilemiştir. Modernitenin tamamlanmamış bir proje olduğunu belirten Habermas, Lyotard'ın postmodern olarak nitelendirdiği hususun Nietzscheci irrasyonelizme gitmek anlamına gelmektedir. Başka bir ifadeyle Lyotard'ın postmodern olarak adlandırdığı fenomenin gerçekte anti-modern olduğudur. 
Aydınlanmanın özgürleştirici projesinin terk edilmemesi gerektiği hususunda 1srarcı olan Habermas, tıpkı postyapısalcıların aksine, söz konusu sorunların yegâne sebebi olarak bütüncül rasyonaliteyi görmez (Bertens, 1995: 113). Habermas'ın daha çok karşısında durduğu rasyonellik, doğa üzerinde egemenlik kurmaya yönelik, öznelci bir bakış açısıyla öznelci bir yapı üzerinde oluşturulan ve öznelerarasılık boyutundan yoksun araçsal rasyonalizmdir.

\section{POSTMODERNIZM VE SANAT İLIŞKISİ}

Dünyada yaşanan teknolojik gelişmeler beraberinde düşünce ve anlayışlarda köklü değişiklikleri getirmiştir. Bu durum, düşünsel dünyada modernizmi de etkilemiş, bununla da kalmayarak sanat ve toplum ilişkilerine de yansımıştır. II. Dünya Savaşı sonrası farklı coğrafyalarda ve farklı sanat çevrelerinde, modern sanatın dönemini kapattı̆ğ, dolayısıyla sanatta yeni bir estetik anlayışının gerekliliği düşüncesi oluşmaya başlanmıştır.

Postmodernist düşünce işte böyle bir ortam içerisinde ortaya çıkmış bir akımdır. $\mathrm{Bu}$ düşünce anlayışına göre, eski olan ve eskiye dair her şey geçerliliğini yitirmiş; estetik, kültürel değerlerin ya da eğilimler geçerliliğini kaybetmiştir (Best ve Kellner, 1998: 19). Modern sanatın seçkincilik, misyon ve özgünlük gibi özelliklerini sorgulayan bir tutum sergileyen postmodernist sanat, modern sanatın katı ve kısıtlayıcı bir anlayışa sahip olduğunu belirtmiştir. $\mathrm{Bu}$ düşünceyle hareket eden postmodernist sanat anlayışı, modern sanattaki yüksek ve popüler kültür ayrımını yok etmeye çalışmış ve modern estetik olgusunu değiştirmeye çalışmıştır. Bu değişimi teknolojik imkanları kullanarak, geçmişten alınan unsurlar ile eski ve yeniyi eklektik bir şekilde kullanıp, farklı anlatım biçimleri oluşturmuştur (Şaylan, 2016: 119).

Postmodernizm üzerine yapılan tartışmalar beraberinde bazı kavram farklılıkları üzerine durulmasını getirmiştir. Örneğin 1980’li yıllara kadar İngilizce metinlerde geçtiği görülen ve aynı anlamda kullanılan "modern art” (modern sanat) ifadesi ve "contemporary art” (çă̆daş sanat) ifadelerinin farklı anlamlar taşıdığı yönünde görüşler oluşmuştur. "Contemporary art" terimi Türkçe de "çăgdaş sanat”, başka bir ifadeyle "günümüz sanatı" olarak çevrilmekte, "modern sanat" terimi ise, "çağcll”, "yeni”" olarak ifade edilmektedir (Danto, 2010: 33-34). Bu iki kavram arasındaki fark, modernizme atfedilen yeni ve ilerleme vurgusuyla bağlantılıdır. Postmodern sanat ifadesi ise, çağdaş sanat içinde eklektik bir eğilimi belirtmek için kullanılmaktadır (Y1lmaz, 2006: 12-13).

Sanat anlayışı bakımından modernizmden keskin bir şekilde ayrılan Postmodernizmin, modernizmin biçimi önemseyen, estetik sınırları olan, seçkinci sanat anlayışı, saflık ve kesinlik 
ilkelerine karşı bir duruş sergiler. Bununla birlikte postmodernizm, ironiyi kullanan, estetik sınırları zorlayan, alaycı bir anlatı yapısı sergileyen, melezlik ve muğlaklığın olduğu bir sanat anlayışı söz konusudur. Pastiş, eleştiri ve nihilist tavrı benimseyebilen postmodern sanat, gündelik hayatla arasındaki sınırları bulanıklaştıran çoğulcu bir anlayışla ilerler. Dolayısıyla postmodernizmin başta pop art olmak üzere mimari, edebiyat ve sinemada görülebilen "her şey kullanılabilir"' düşüncesiyle hareket ettiği söylenebilir Sanatsal anlayışta köklü bir değişimin yaşanmasına neden olmuş olan bu durum sanatın çok yönlü, çok dilli yapısı; deneyimi öne alan, dilsel, performatif ve kavramsal önermelerin, teknolojik yeniliklerle uzam ve zaman algısında köklü değişimler sunmuştur. Oluşturulan bu yapı sanatta parçalı, karmaşık ve eklemli bir yapılaşmayı görünür kılmıştır. (Connor, 2008: 12). Postmodernizm sanat anlayışının temelinde olan bu çoğulculuk ve modernizmden farklı olarak biçimsel formların kullanılması, (Lyotard, 1990: 57-58), sanat anlayışındaki biçimsel normlar ile biçimsel yöntem çeşitliliğidir (Sarup, 2010: 240). Hal Foster'a göre ikisi arasındaki farkın ise normun modernist bir kavram iken yöntemin postmodernist bir kavram olarak öne çıkmasıdır. Normların saygın ve oturmuşluk olarak gösterilirken, biçimsel yöntem değişken, çeşiklilik gibi özelikler içermektedir (Foster, 2009: 254). Dolayısıyla postmodernist dönem sanat anlayış1, popüler ürünler ve yaşamın sanata dönüşmesine neden olmasından ötürü yüksek sanatı olumsuz etkilemiştir. Baudrillard'a göre bu durum tüketim nesnelerinin sanata eklemlenmesi ile postmodernizmin sanatsal yansıması ve popüler kültür imgelerinin 20. yüzyıl başında, hazır nesneleri sanat eseri olarak sunulmasına neden olmuştur (Baudrillard, 2012: 2).

Nesneler de sanat eseri olabilir. Çünkü burada önemli olanın onu yaratan sanatçının ne şekilde düşündüğü veya tasarladığıdır. Dolayısıyla postmodernizmin, modern sanatın kurumsallaşmış yapısına, sanat yapıtının kutsanmasına karşı bir duruş sergilediği söylenebilir. Sanatı gündelik yaşamın objelerinden sinema yıldızlarına kadar her şeyi dahil eden bu anlayış, bütün objeleri birer popüler kültür nesnesi haline getirmektedir (Baudrillard, 2012: 133). Bu yaklaşım bir bakıma tüketim toplumunun ve imajların gerçekliğinin kabulüdür (Featherstone, 2005: 55). Buda modernizmin sanat eseri olarak ifade ettiği özgün yapıtların, postmoderniz sanat anlayışında çoğaltılıp ve aynı zamanda kopyalanabilir birer ürüne dönüşebileceği anlamına gelmektedir.

\section{POSTMODERNIZM VE SINEMA İLİŞKISİ}

Çalışma konusu olan David Lynch’in “Kayıp Otoban” filminin postmodernist bir bakış açısıyla analiz etmeden önce postmodernist sinema anlayışını ve postmodernizmi bir sanat 
formu olarak gerçek manada neyi tanımladığını bilmek gerekir. Modernizm sonrası anlamı anlamına gelen postmodernizm kapitalizm, sanayileşme ile başlayan ve ağır toplumsal sorunları beraberinde getiren bir süreç sonrası modernite ile ilişkili bu sosyal formların başlatanı başlatanı olarak ifade edilebilir. Bu formlardan biride 20.yüzyılda var olmuş ve sonraki dönemde büyük gelişme göstermiş olan sinemadır. Dolayısıyla postmodernizmin sinema üzerindeki etkisini anlamanın yolu, öncelikle postmodernizmin sinema ile olan ilişkisinin bilinmesinden geçer.

Farklı üslup ve yönelişleri bünyesinde barındıran postmodernizmin film anlatı yapısı ile kurduğu ilişkiye bakıldığında bazı özellikler açısından avangart sinemaya yakınlığının olduğu görülmektedir. Bu yakınlık, avangart sinemada kullanılan filmsel ritim, simge ve konunun zor anlaşılmasını kolaylaştıran ancak bunu yaparken de filmin olay örgüsü ve anlamının izleyici tarafından kolayca anlaşılmasına izin vermeyen bir anlatı dilidir.

Avangard (öncü) sinema tarihi, 20. yüzyılın ilk çeyreğinde Fransız deneysel sinemasıyla başlamaktadır. 1920'de Paris'de (Yedinci Sanatın Dostları) CASA' nın faaliyete geçmesiyle başlayan sinemayı ciddiye alma süreci, daha sonra Quartier Latin'in aydın ve elit izleyicilerine yönelik kurulan "Stüdio 28", "L'oeil du Paris", "Studio des Ursulines" gibi salonların açılmasıyla hızlanmış ve bu salonlarda gösterilen ve üzerinde tartışılan filmlerin yapımı özendirilmiştir (Richter, 1998: 84-86).

Postmodernist anlatı yapısına sahip olan bu filmler, olay örgüsü içerisinde yer alan psikolojik sorunlar üzerine oluşan odipal süreçlerle bağlantılı karmaşık olay aktarımları sergileme potansiyeli taşır. Bununla birlikte sembolik göndermeler, yaratılan metaforlar ve çağrışımlar bu film anlatı yapısını kapsamaktadır (Abisel ve Eryılmaz, 2010: 163). Postmodern sinema küreselleşen dünyanın ideolojik yansıyışın bir ürünü olarak, içeriğinde gerek toplumsal, politik, kültürel gerekse de psikolojik özellikler taşımakla birlikte daha çok estetik bir kategori olarak kendisini dışa vurur. Bu dışa vuruşta her şeyin sanat olabileceğine dair bir ön kabulle hareket eder. Bir melez sanatsal yaklaşım olan postmodernist sinema, kendisini toplumsal bir boşluğun içerisine yerleştir ve sunar.

Avrupa merkezli bir akım olan modernizmin dayandığı güç 18. yüzyıldaki aydınlanma hareketinden gelmektedir (Harvey, 2014: 25). İlerleyen zamanla birlikte modernist düşüncenin etkin olduğu bir evrende yaşanan birinci ve ikinci dünya savaşı, ekonomik ve siyasi çalkantılar, soğuk savaş dönemi ve sonrasında toplumda yaşanan dönüşüm, beraberinde yeni bir anlayışın oluşmasına olanak tanımıştır. Bu anlayışla birlikte sanatta soyutun yanına tekrar figür geçmiş, geçmişten esinlenmeler sanatta alan bulmuş, pastiş ve eklektik anlayışın öznel olana karşı çıkmasıyla birlikte sanata postmodern anlayış ortaya çıkmıştır. Bu ortaya çıkış 1960'larda değişken şiddette de olsa sanatın alanlarında kendisini göstermiştir. Sanatta postmodern 
anlayışın sinemada karşılık bulması ise 1980'li yıllara doğru olmuştur. Bu yıllardan itibaren film anlatısında çok zamanlılık, metinlerarasılık, pastiş, parçalı kurgu gibi postmodern olarak tanımlanan unsurlarla kendini göstermiştir. Postmodernizmin sinema aktarımlarına bakıldığında başta nostalji olmak üzere vurgunun içerikten biçeme kayması, klasik gerçekçi anlatının yerine görüntünün önde olduğu bir temsil sinemasının önem kazandığı görülmektedir (Büyükdüvenci ve Öztürk, 1997: 22-23). Ayrıca zamanın yaşanan anın içine hapsolması, tüketim kültürü, yabancılaşma, kopuş konuları da ele alınmıştır.

Modern sinema veya modernist sinema terimi "yaratıcı sinema" veya bir başka aktarımla "auteur sinema" anlayışı olarak bilinmektedir. Modernist sinema anlayışının temelinde, çağını sinema yoluyla anlama ve onu sorgulayan ve aynı zamanda bu sorgulamaya seyirciyi de katan bir sinema anlayışıdır. Postmodern sinemanın her ne kadar modernist sinema anlayışıyla dönemi sorgulama bakımından ortak bir yaklaşım içinde olduğu görülse de sinemadan yaratıcılık kavramından kopmuş olmasıyla ayrılmaktadır (Connor, 2001: 261). Pastişin varlığını “bireysel öznenin kaybolması”’ olarak niteleyen Jameson, bunun sonucu olarak, kişisel üslubun giderek zorlaştığını belirtmektedir (Jameson, 1990: 76). Bu duruma örnek olarak "Amerikan Grafitisi" (American Graffiti-1973), "Çin Mahallesi (Chinatown1974), "Yıldız Savaşları” (Star Wars (Yıldız Savaşları) gibi filmleri verilebilir. Bu yapımlar tarihsel bir duruma dikkat çekmekten ziyade, bir dönemin kültürel yaşam deneyimlerini yeniden aktarmaktadırlar (Jameson, 1990: 79).

Sinema filmlerindeki üslup ideolojisinin gerilemesiyle birlikte, postmodernist anlatıda sanatçının başvurabileceği tek kaynak vardır ve bu kaynakta geçmiştir. Postmodern sinema geçmişten aldığı motif ve imgeler aracılığıyla yüzeysel ve parçalanmış hikâyeler aktarır. Jameson'a göre bu durum yaşanan zaman eksikliğinden kaynaklanmaktadır (Jameson, 1990: 78). Sinemada postmodern söylemin birincil aktarım biçimi kolajdır (Harvey, 2014: 65-67). Kolaj kullanımına örnek olarak Tarantino filmleri verilebilir. "Kill Bill 1- Kill Bill 2" (Bill'i Öldür 1-2) filmi, Bill tarafından yönetilen çeteden ayrılan eski 'kara mamba' lakaplı, gelinin düğün günüde kendisine yapılanları hatırlaması ve ona büyük kötülükler yapan bu ölüm çetesinden intikam almasını anlatmaktadır. Filmin kadın karakteri çete ile bir mücadeleye girişirken, üzerinde uzak doğu savunma sporlarının önemli isimlerinden ve aynı zamanda aksiyon filmlerinin öncü isimlerinden biri olan Bruce Lee ile bütünleşmiş olan sarı-siyah kostüm ve elinde silah olarak bir Japon samuray kılıcı bulunmaktadır. Tarantino bu filminde sinema tarihinden ödünç aldığı birçok metni kendi içinde eriterek yeni bir anlatı yaratmıştır. 
Dolayısıyla "saf olan türler" yerini "melez" türlere, filmlerdeki metinsel yapılar da yerini metinlerarasılığa bırakmıştır.

Modleski, bu tür filmlerde rahatsızlık boyutunda kullanılan ve bazen de parodileştirilen şiddet ve ölümün burjuva kültürünün değer verdiği aile ve ideolojiye bir saldırı olarak nitelendirmektedir (Modleski, 1998: 201). Bu duruma verilecek bir diğer örnek ise David Lynch'in "Mavi Kadife" (Blue Velvet-1986) filmidir. Filmin başında sıradan insanların sıradan ve aynı zamanda monoton olarak ilerleyen günlük hayatlarından bir kesit aktarılmakta olduğu hissi, filmin karakterlerinden biri olan Jeffrey’in kesik bir kulak bulmasıyla değişir. Filmdeki bu değişim giderek artan bir rahatsızlık boyutuna ulaşır. Yaşanan bu durum film karakterlerinden Jeffrey'nin, hiçbir şeyin göründüğü gibi olmadığını fark etmesine neden olur. Filmde sunulan kesik kulak mutlu ve huzurlu olarak sunulan Lumberton'dan, karanlık ve bilinmezliklerle dolu olan Lumberton'a geçişi sağlayan sadece bir araçtır. Kulağın bulunması sırasında müzik değişir ve atmosfer kararır. Film anlatısındaki bu göstergeler seyirciye iki farklı yaşam biçimiyle karşı karşıya olduğunu gösterir (Easthope, 2004: 129). Buda sıradan olanla olmayan arasında bir sınır olmadığı göstermektedir (Connor, 2001: 260-264). Eaglaton'a göre Postmodernizm, yerel, bölgesel veya kendine özgü olanın gücünü açığa çıkarmış, onu özgürleştirmiş ve yeryüzünde homojenleşmesine katkı sunmuştur (Eaglaton, 2015: 43).

Postmodernizmin göstergelerinden bir diğeri de teknolojinin gelişimiyle bağlantılı olarak imaj kopyalanmasıdır. Başka bir ifadeyle gerçekle, gerçek olmayan arasındaki farkın fark edilmemesidir. Bu duruma örnek olarak Ridley Scott'un "Bıçak Strtı” (Blade Runner1982) filmi verilebilir (Harvey, 2014: 323). Filmde Deckard'ın görevi insan olmak isteyen androidleri bulmak ve yok etmektir. Ancak bu robotların tasarımlar mükemmellik boyutundadır. Bundan dolayı onları insanlardan ayırmak mümkün değildir. $\mathrm{Bu}$ objeler Baudrillard'ın bahsettiği “'suretler', nesnelerin ya da olayların temsilleri ya da kopyalarıdır. Kellner'a göre toplumsal hayatın üzerinde egemenlik kuran bu suretlerin teknoloji sayesinde üretilebilmektedir. Artık bu dünyada modeller hüküm sürmektedir (Kellner, 2000: 372-373). “Gerçek', olanı önceleyen modeller olarak 'taklitler', bir müddet sonra toplumsal düzene egemen olmaya ve toplumu "hipergerçeklik" olarak oluşturmaya başlar (Baudrillard, 2014: 72-73). 


\section{5. ÇALIŞMANIN YÖNTEMI}

Bu çalışmada sinemada 1980'li yıllardan itibaren varlığını hissettiren postmodernist anlatının David Lynch'in yönetmenliğini yaptığı Kayıp Otoban filmi bağlamında incelenmiştir. Çalışma konusu olan bu filmin seçilme nedeni klasik anlatı dışında kalması, çoklu parçalanmışlık yapısını kullanması ve kapalı bir içerik aktarımı tercih etmesidir. Kayıp Otoban filmi, neoformalist yaklaşım çerçevesinde incelenmiştir.

Neoformalizm, temeli Rus Biçimciliği'ne dayanan, David Bordwell ve Kristin Thompson tarafından geliştirilen bir yöntemdir. $\mathrm{Bu}$ yöntem sanat dallarında anlatısal olarak tamamlanmış bir sanat eserinin oluşumunu ve ilkelerini inceler.

Neoformalist kuram, bir filmi algısal ve göstergebilimsel özellikleri arasında fark olduğu, sinema perdesine yansıyan ile perdeden zihne yansıyan arasında farkın olabileceğinden hareket etmektedir. Bu yaklaşım sanatçıdan ziyade sanat eserini merkeze almakta ve eseri izleyicinin algısında tamamlamaktadır. Söz konusu yaklaşım açısından yönetmen, filmi oluşturmak için teknik imkanları kullanarak hikâye üzerinde seyircinin hafızasında bir fabula yaratmakla mükelleftir. Dolayısıyla David Lynch'in yönetmenliğini yaptığı Kayıp Otoban filmi klasik sinema anlatısından farklı bir olay aktarımına sahip olması ve alışkanlığı bozacak bir biçim oluşturmuş olması nedeniyle yukarda da belirtildiği gibi neoformalist yaklaşımla ele alınması, filmin anlatısının anlaşılmasını kolaylaştıracaktır (Bordwell, 1989: 370-372) Neoformalist yaklaşım, seyirciyi sanat yapıtına aktif olarak katmaktadır. Burada seyirci gerek sanat yapıtındaki ipuçlarından ve gerekse de önceki sanatsal ve günlük yaşam deneyimlerinden yola çıkarak yapıtı değerlendirebilmektedir. Thompson'a göre bu yaklaşım, çekilmiş olan bir filmin algısal ve göstergebilimsel özellikleri arasında bir ayrımdır (Thompson, 1988: 5-10).

Neoformalist yaklaşım için, sanatta önemli kavramlardan birisi de eseri yaratırken kullanılan araçlardır. Burada kastedilen araçlar, sanat yapıtında kullanılan kamera ve kamera hareketi, diyalog, kostüm, tema gibi anlatı unsurlarıdır. Bu yaklaşım için sinemanın anlatı unsurları ve bu unsurların biçimsel organizasyonunda, farklılaştırma yaratmak ve sinemasal yapıyı inşa etmek için eşit öneme sahiptir (Bordwell, 1987: 374). Thompson'a göre araçların sadece yapıttaki anlamı ifade etmek için değil, aynı zamanda farklılaştırma yaratabilmek için de kullanılmaktadır (Thompson, 1995: 106-107). Dolayısıyla çalışmanın neoformalist yaklaşım doğrultusunda incelenmesinin temel sebebi, sinemanın çok katmanlı yapısından kaynaklanmaktadır. Başka bir ifadeyle ortaya çıkarılan eserin metinsel aktarımların dışında, sinemanın başka anlam yaratma unsurlarının kullanılarak oluşturulabilmesidir. 
Anlatı yapısı bakımından göreceli bir karışılılı sergileyen postmodern filmlerde, bu anlatılara özgü anlam yaratan unsurlar göz önünde tutan analiz yöntemleri ile irdelenmesi önem teşkil etmektedir. Aksi taktirde bu tarz filmlerin sadece içerik üzerinden ele alınarak film estetiğinin analiz edilmesi, yapımın sanatsal yapısının bir bütünlük içinde kavranmasını zorlaştıracaktır. Bundan dolayı çalışmanın neoformalist yaklaşım çerçevesinde analize tabi tutulmasının temel motivasyonlarından birini oluşturmaktadır. Bu yöntemin tercih edilmesinin bir diğer nedeni ise bitmiş bir anlatı yapısı olan filmin kendisini irdeleyerek sonuca yönelik alternatif bir anlayışın geliştirmesidir.

\subsection{Kayıp Otoban (Lost Highway-1997)}

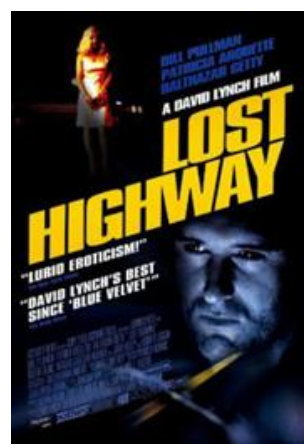

Yönetmen: David Lynch

Oyuncular: Bill Pullman, Patricia Arquette, John Roselius, Louis Eppolito, Michael Massee, Robert Blake

\section{Senaryo: David Lynch, Barry Gifford}

Filmin Konusu: Film, bir gece kulübünde müzisyen olarak çalan Fred Madison'ın (Bill Pullman) başından geçen garip olayları anlatıyor. Filmin olay örgüsüne bakıldığında, bir gece vakti hızla ilerleyen bir arabanın farlarının aydınlattığı ve işaret çizgilerinin arabanın hızına paralel bir biçimde aktığı bir sahneyle başlıyor. Zifiri karanlık bir alana girildikten sonra, filmin karakterlerinden Fred'in gergin bir ifadeyle sigarasını içtiği görülmektedir. Geceden sabaha doğru geçen zaman aktarımında karakter hala aynı yerdedir. Sabah 1şıklarıyla birlikte yüzünün iyice görülmesiyle birlikte filmin karakterlerinde Fred'in yorgun olduğu seyirciye yansımaktadır. Kapı zilinin çalması ve ardından interkomdan "Dick Laurent öldü" sesini duyulmasıyla sahne devam etmektedir. 
Bir sonraki sahnede Fred elindeki müzik enstümanını yerine koyarken görülmektedir. $\mathrm{Bu}$ arada koridorun diğer tarafında ise üzerinde kırmızı bir gecelik ve elinde bir kadeh Fred'in eşi Renee (Patricia Arquette) görünür. Her ikisi farklı köşelerde durmaktadır. Aynı zamanda sahne içerisinde Fred karanlık tarafta dururken, Renee ise 1şığın vurduğu aydınlık taraftadır. Fred çalışacağı kulübe gideceğini ve onunda gelmesini istediğini belirtir. Ancak eşi Renee kitap okuyacağını bundan dolayı gelemeyeceğini söyler.

"Luna Lounge” adlı klüpte sahneye çıkan Fred, sahne sonrası karısını arar ancak cevap alamaz. Cevap alamamasından dolayı yüzünden hayal kırıklığı ve öfke vardır. Bu öfke ve hayal kırıklığının sebebi, karısının onu aldatmış olabileceği şüphelenmesinde kaynaklanmaktadır. Fred'in yüzüne yansıyan kırmızı 1şıktan evin duvarına yansıyan 1şığa yapılan geçişle onu merdivenlerden yukarıya doğru çıkmakta olduğu gösterilir. Yatak odasına ilerleyen Fred, karısını uyurken bulur. Denee'nin üzerindeki gecelik, yüzüne vuran kırmızı 1şık ile bir arzu nesnesi olarak sunulur. Bununla birlikte Renee, Fred için aynı zamanda kötülük bekleme potonsiyeli taşıyan, güvenilmez ve yakınında olduğu halde ulaşılamayandır.

Sonraki sabah kapıya bırakılan gazeteyi almak için dışarıya çıkan Renee, eşiğe bırakılmış bir paket bulur. Yukarı çıkarken elindeki paketi Fred görür. Fred kuşkulu bir şekilde elindekinin ne olduğunu sorar. Paket açıldığında çıkanın bir video kaseti olduğu anlaşılır. Tereddüt içerisinde pakette çıkan kaseti izlemeye başlarlar. Kasette, sadece evlerinin dişardan çekilmiş bir görüntüsü vardır.

Bir başka sahnede yatakta uzanmış olan Fred, bir önceki geceyi düşünmektedir. Sanki kendisi sahnedeyken karısının başka bir adamla salondan çıktığı düşüncesine kapılır. Fred korku ve tedirginlik içerisindedir. Karısına ilişkin hissettiklerinden rahatsız gibidir. Karısına gördüğü bir rüyadan bahsetmeye başlar. Rüyasında eve geldiğinde karısının sesini duymasına rağmen kendisini göremediğini anlatır. Koridorda ise bir sis perdesinden söz eder. Ancak rüyasındaki bir sahneyi anlatmaz. Bu sahne yatak odasına girdiğinde karısının yatakta yattığını ancak yaklaştığında onu öldürülmüş olarak bulduğudur.

Sonraki saban Renee gazeteyi almak için dişarı çıktığında yeni bir paket görür. Fred ve Renee de endişe derinleşir ancak gene de gelen kaseti izlemeye başlarlar. Kasette evlerinin ön cephesinde çekilmiş bir görüntüyü içermektedir. Ancak bu sefer kasette evin içinin de görüntüleri bulunmaktadır. Bu görüntülerde ikisinin uyurken ki görüntüleridir. Bundan dolayı tedirgin olan ikili polisi ararlar ve eve gelen polisler gerekli araştırmalar yapar ve onlara çeşitli 
sorular sorar. Bu sorulardan bazıları özel hayatlarına ilişkin imalar içermektedir. Bu imalar polisler ile Fred arasında soğuk bir hava oluşturur.

Polislerden biri evde kamera olup olmadığına yönelik sorular sorar. Renee, olmadığını çünkü kocasının görüntülenmeyi sevmediğini belirtir. Bunun üzerine Fred, kamera kullanmaktan çok, kendi yöntemlerimle hatırlamayı sevdiğini belirtir. Burada kamerayla kaydetme ve görüntüleme, bellek ve duygu arasındaki ilişki, sözde kamera “objektifliği” gibi postmodern dönem insanını en çok ilgilendiren konulara küçük bir gönderme söz konusudur. Polislerden biri, kamerayla ilgili Fred'in yaklaşımının anlamının ne olduğunu sorduğunda ise Fred ne olduğunun değil, onu nasıl hatırladığım önemsediğini belirtir.

Filmin bir başka sahnesi filmin karakterlerinde Andy’nin evinde verdiği partidir. Herkesin keyfinin yerinde olduğu partide Renee, kocası Fred'den kendisine bir içki getirmesini ister. Fred içki almaya gittiği sırada, kalabalığın içerisinde kendisine birinin yaklaştığını görür. Bir ölünün yüzünü andıran bembeyaz bir surat ve siyah gözleriyle huzursuz edici bir havası olan adam, daha önce tanıştıklarını belirtir. Onu hatırlamadı̆̆ını belirten Fred, kendisiyle nerede tanıştığını sorar. Esrarengiz adamın cevabı "senin evinde" olur. Gizemli adam, Fred'in ona kuşkuyla baktığını görünce cebinde bir telefon çıkarır ve onu aramasını ister. İnanmamasına rağmen kendi telefon numarasını çeviren Fred, karşısında duran adamın sesini duyar. Bunu nasıl yaptığını sorduğunda ise, adam telefonun ucundakine sor der. Fred, telefondaki adama evine nasıl girdiğini sorduğunda aldığı cevap "beni sen davet ettin. Davet edilmediğim yere gitmem” şeklinde olur. Kim olduğunu soran Fred, yankılanan bir kahkaha ile cevabını alır.

Ev sahibi Andy’e gizemli adamın kim olduğunu soran Fred, onun Dick Laurent'in bir arkadaşı olabileceğini öğrenir. Bu durumdan rahatsız olan çift partiden ayrılır. Fred yolda karısına partiyi veren Andy’i nereden tanıdığını sorduğunda "Moke's" adlı bir bar da cevabını alır. Onunla bir iş hakkında konuştuğunu söyler ancak şu anda ne tür bir iş olduğunu hatırlamadığını belirtir. Renee'nin bu cevabı filmin ilerleyen bölümlerinde yaşanacak gizeme yönelik bilgiler barındırmaktadır.

Eve döndüklerinde Fred pencereden yansıyan gölge ve 1şıkların olduğunu görür. Karısını arabada bırakan Fred eve bakmak için yalnız gider. Kendisini karanlık bir koridorda bir karanlığın içinde bulur. Yaşadıkları ona bir başka dünyanın kapılarını aralamış gibidir. Karşısında gizemli bir şey varmış gibi kameranın odak noktasına bakar. Kameranın bakış açısı izleyicinin bakışına dönüşür. Bu bakış açısı Fred'in baktığı boşluğa doğru yerleştirilir. Daha 
sonra Fred kameraya sırtını dönerek oradan uzaklaşır. Kapıda bekleyen karısını alır ve içeri girerler.

Sonraki sahnede Fred elinde içinde kaset olan bir paketle salona geçerken görülmektedir. İçinde kaset olan paketi açar ve izlemeye başlar. Önceki kaset görüntüleriyle paralellik içermektedir. Evin dışarıdan çekilmiş görüntüsüyle başlar. Sonra evin içinden çekilmiş görüntüler belirir. Görüntülerde kamera evin koridorlarından ilerleyerek yatak odasını gösterir. Burada Fred'in üstünün kana boyanmış olduğu, yatağın hemen yanı başında vahşice öldürülmüş karısının cesedi başında göstermektedir. Biranda patlayan flaşlar sonrası Fred kendisini polis karakolunda bulur. Sorguda yöneltilen suçlamaları kabul etmeyen Fred, buna rağmen tutuklanır, yargılanır ve ölüm cezasına çarptırılır.

Hücrede tek başına kalan Fred'in gözlerinin önünde karısının öldürülmüş biçimini gitmemektedir. Uykusuzluk çeken Fred, sürekli bir şeyler görmektedir. Bunlardan biri de kumsalda alevler içinde yanan bir kulübe görselidir. Yanan kulübenin görüntüsü sondan başa doğru ve ağır çekim ile gösterilir ve yangının bir patlamayla başladığı vurgulanır. Yanan kulübenin kapısında bir adam belirir. Duruma şaşırmış gözlerle bakar. Fred'in kaldığı hücrede 1şıkların belirdiği görülmektedir. Koridorlardaki ışıklar söner ve karanlık her tarafı kaplar. Bu karanlıktan filmin başında verilen otoyola geçilir. Otoyol kenarında duran biri, gök gürültüsü sonrası çakan şimşeklerle fark edilir. Bu adama bir anda beliren üç adamın seslendiği görülür. Buradaki görüntülerin tersten verilmesi (sondan başa doğru) zaman ve fillm anlatı düzeyi ile gerçekliğin aktarımına yönelik bir yaklaşımdır. Bununla birlikte David Lynch’in Kayıp Otoban filmi, aslında bilinçten alt bilince doğru giden yoldur. Üst benliğin kabul edilmezliğinden dolayı bastırıldığı, yok sayıldığı bir yere giden yola bir bağlantıdır.

Film anlatısının sonraki sahnesinde hücre kontrolü yapıldığı görülmektedir. Ancak yapılan kontrolde Fred'in bulunduğu yerde bir tuhaflık vardır. Tuhaflığın nedeni ise az önce yol kenarında görülen Pote adında genç adam yatmaktadır. Bu tuaf durum sorgulanır ve suçlu olmadı̆̆ı anlaşılan Pote serbest bırakılır.

Filmin bir başka sahnesinde Pete, çalıştığı tamircide görünür. Ancak onu takip eden iki dedektif vardır. Pete'in çalıştığı tamirci dükkânına sert bir görünüme sahip olan Dick Laurent adında biri gelir. Arabasının bakımının yapılmasını ister. Pete arabanın motorunu kontrol ederken Dick Laurent onu kast ederek şehirde Pete'nin en hassas kulaklara sahip olduğunu söyler. Pete'ye onun canını sıkan bir durum varsa müdahale edebileceğini söyler. Bu benzetme 
önemlidir. Çünkü Fred bir caz müzisyenidir ve doğal olarak tıpkı Pete gibi kulakları çok hassastır.

Sonraki sahnelerden birinde ise Pete'i çalışırken görmekteyiz. Fonda ise filmin başında Fred'in çaldığı caz şarkısı duyulmaktadır. Ancak Pete bu şarkıdan rahatsız olur ve radyoyu kapatır. Bu sırada Dick Laurend içinde sarışın bir kadın arabasıyla tamirhaneye gelir. Gelmesindeki neden arabasını tamir ettirmektir.

Filmin bir başka sahnesinde Alice ve Pete'in olay yerinden uzaklaşmak için hareket halindedirler. Alice değerli bulduğu takıları toplar ve beraber evden ayrılırlar. Gidecekleri yer Alice'in bahsettiği adamın bulunduğu yerdir. Aslında Alice'in bahsettiği bu gizemli adam, aslında bilinçaltına yapılan bir göndermedir.

Geldikleri yerde kapıyı açan olmayınca Alice kapıyı iterek açar. Alice için engeller söz konusu olamaz. Ancak içerde kimse yoktur. Bunun üzerine arabada beklemeye karar verirler. Arabada belli süre bekledikten sonra Alice kulübeye girmek için arabadan iner. Pete, ayağa kalkmak için doğrulur ve arkasını döndüğünde Fred'e dönüşmüş olduğu görülür. Fred arabanın içerisinde bekledikleri gizemli adamı görür. İçeri giren adamı takip eden Fred, içerde Alice'i arar ancak bulamaz. Bunun üzerine gizemli adama Alice'in nerede olduğunu sorar. Adam onun Alice olmadığını, adının Renee olduğunu söyler. Paniğe kapılan Fred olay yerinden uzaklaşır.

Yine otoban görülür. Burası bir anlamda alt benlikteki ara bölgededir. Yol sonunda "Kayıp Otoban Moteli" (Lost Highway Motel) kadraja girer. Motelden içeri giren Fred, 26 numarada Renee ve Eddy’yi görür. Ancak kapıyı açmaz. Belli bir süre sonra odadan çıkan Renee olur. Üzerinde beraber partiye gittikleri elbise vardır. Arabaya binerek oradan uzaklaşır. İçeriye giren Fred, Eddy’yi zorla dışarı çıkarır ve çölün yolunu tutarlar. Çölde onu arabadan çıkarır ve öldürür.

\subsection{Filmde Postmodern Unsurlar}

Kayıp Otoban (Lost Highway) filmi, postmodern bireyin yaşam şartları içerisinde kendini oluşturma durumunda kalması üzerinden ilerleyen postmodernist bir hikâye anlatısına sahip bir yapım. Los Angeles'ın banliyösünde geçen filmde Fred'in varoluş sorunu, karısının (Renee) onu aldatmasında şüphelenmesiyle başlar. İyimserlik, umut ve mutluluktan söz edilemeyen bu ortam içerisinde filmin karakterleri belirsizlik ve korkuyla baş etmek zorundadırlar. 
Neoformalizm, soyut ve genel varsayımlarla hareket etmeden filmin anlatısını sinemanın yaratımı içinde anlamaya çalışır. Bunu yaparken de seyircinin gerek algısal ve gerekse de bilişsel etkinliğini göz önünde bulundurarak, aktif bir yerde konumlandırır. $\mathrm{Bu}$ doğrultuda bakıldığında izleyiciye sınırlı bir bakış açısı sunan film, yeterli bir anlama yönelik bilgi aktarımı yapmamaktadır. $\mathrm{Bu}$ aktarım şekliyle izleyici, anlatım metni içerisine yerleştirilmiş olan kapalı anlamları çözmek zorunda bırakılır. Kayıp Otoban filmi içerisinde yaratılan bu bilinmezlik seviyesini karakterler üzerinde yapar. Ancak bu aktarımda hiyerarşik bir durum söz konusu da değildir. Söz konusu olan bu durumun nasıl oluştuğu ise bir bilinmezliktir. Mevcut durumdan çıkış için gerekli olan bilgiler ise çalışmanın çeşitli yerlerine serpilmiştir (Araz, 1999: 21).

Filmin yönetmeni David Lynch filmde yarattı̆ğ ve bilinmezliklerle örülmüş anlatım diliyle gerçeküstü bir atmosfer oluşturmaktadır. Yönetmenin anlatı dilinde belirsiz bellek birey tarafindan güvenilirliği sorgulanan ve sorun yaratan bir olgudur. Bu olgudan dolayı onun filmlerinde bilinmezlik, paronoya mevcut dünyada var olan ama görülemeyen bir cehennemdir. Yönetmenin anlatısında olan bilinç altına yönelik yaklaşım, sürreel filmlerdeki ruhsal dengesizlikler içerir. Film karakterlerinin ruhsal yapılarında takıntılı cinsellik, tutkuyla örülmüş melankoli, kötümserlik ve belirsizlik söz konusudur. Sahip oldukları bu özellikleri doğrultusunda yaptıklarıyla hayatları anlam kazanmaktadır (Özdemir, 2003: 15) Lynch'in filmlerinde insan özne olarak evrenin merkezinde yer almamaktadır. Tıpkı bu film karakterlerinde olduğu gibi, karakterler özne olma vasıflarını yitirmişlerdir. Yaratılmış olan bu durum, bireyin bilinç yapısının derinliklerinde yatanı bulmaya yöneliktir. Tıpkı Fred gibi var olan dünyanın içine girmeye çalışırsa da kabul görmemekte ve geldiği yere savrulmaktadır.

Kayıp Otoban filmi belli bir izlek üzerinden ilerler ve film karakterleri bu izleğin peşinde gitmektedirler. Bu doğrultuda anlatısını gerçekleştiren filmde seyirci “öteki” olan karakterlerle karşılaşır. Kayıp Otoban filminde bu durum, müzisyen Fred Madison üzerinden paronaya, kaous ve karmaşa üzerinden aktarır. Bu aktarım sırasında kurgudaki parçalılık ve metine sağlanan gerek anlamsal ve gerekse de göstergesel olarak katmanlar yaratılmıştır.

Film anlatı yapısı karakterlerin iç dünyası üzerinde ilerlemekte ve zihnin derinliklerinde var olan tutku, paronaya ve karmaşayı yansıtmaktadır. Karakterler, bilinç altında yatan şizofrenik duygularla birbirlerine yönelirler. Film karakterlerinde olan Fred Madison'un (Bill Pulman) karısı olan Renee'in (Patricia Arquette) kendisini aldattığına yönelik kuşkularla başlamaktadır. Karısının nasıl bir geçmişe sahip olduğu konusunda bir fikri olmayan Fred 
Madison bundan dolayı kafası sürekli olarak soru işaretleriyle dolaşmaktadır. Bunun sonucunda da yaşadığı kişilik bölünmeleriyle gelişen olaylar sonunda cinayetle sonuçlanır. Film anlatısında her ne kadar şizofren birinin bir katile dönüşmesi olarak görülse de bir anlamda başka birinin içine sığınmış olan bir şizofren katildir. Zizek'e göre filmin karakterlerinden Fred Madison imkânsız olanı isteyen ve etrafı engellerle çevrilmiş biridir. Filmde görünürde kocasına sadakati olmayan Renee’yi öldürüldüğü için idama cezasına çarptırılmıştır. Ancak Fred'in hücrede bir anda başka birine (Pete) dönüşmesi ve sonrasında ortaya çıkan Renee'nin sarışın femme fatale olarak ortaya çıkışı (Alice) ve baştan çıkartılan genç, aynı zamanda tehlikeli yaşamına geçilmesidir. Yaşanan bu geçiş Renee'nin katilinden sonra Fred'in kendisini güçlü bir âşık olarak sunmasıdır (Zizek, 2001: 7-8).

\subsection{Filmde Karakterin Sunumu}

Geleneksel sinema anlatısındaki karaktere seyircinin ilgisi, kahraman olarak görmesi ve özdeşleşme kurma isteği, postmodernist filmi için söz konusu değildir. Bunun nedeni, postmodern film anlatılarındaki karakterlerinin sahip oldukları özelliklerden kaynaklanmaktadır. Bununla birlikte geleneksel sinemada anlatısında var olan güçlü erkek ve güzel kadın imgeleri, postmodern sinemada yerini günlük yaşamda var olan sıradan insanlara dönüşmektedir. Bu sıradanlık içerisinde karakterler, birileri tarafından amaçları doğrultusunda yönlendirilebilmektedir. Tıpkı çalışma konusu olan filmde Renee tarafından yönlendirilen Fred veya Alice tarafından yönlendirilen Pete gibi.

Filmin erkek karakterlerinden olan Fred, geceleri kulüplerde müzisyen olarak çalışan biridir. Bu durum ona gerek çevreden ve gerekse de toplumdan uzaklaşmasına neden olmuştur. Karısı Reene ile büyük bir evde yaşayan Fred, onu yetirince tanımamaktadır ve neler yapabileceği yönünde kuşkular taşımaktadır. Bu kuşkuların başında Renee'nin sadakati üzerine duyduğu şüphedir. Bu şüphe filmin anlatısının kurgulandığı temel unsurlardan bir tanesidir.

İkincisi ise yatak odasında olanların başkaları tarafından bilinmesidir. Gerçek anlamda karısı Renee'ye sahip olamayan Fred, sonraki süreçte Peter aktarımında da Alice'e sahip olmak için gösterdiği yoğun çabanın temelinde de bu vardır. Alice önceki aktarımda karısı Ranee'yi temsil ediyor. Alice, kendisine asla sahip olamayacağını söylediğinde Peter'in Fred'e dönüşmesi onun yaşadığı travmatik durumun etkisi olduğu söylenebilir.

Renee'nin Fred' e karşı tutumu onun etkinliğini göstermektedir. Bu duruma örnek olarak ikili arasında geçen diyalog verilebilir. Fred'in Renee'ye “Hala seni güldürmeyi 
başarabiliyorum" demesi sonrası Renee "Gülmeyi sevdiğini” belirtiyor. Burada Renee'nin vurgulamaya çalıştığı aslında beni güldürenin sen değilsin. Gülmeyi sevdiğim için güldüğümdür.

Postmodern filmlerin erkek karakterler birileri tarafından harekete geçirilen, ilgi duyduğu kadının peşinden gidendir. Peşinden gittikleri kadınlar, olay örgüsü içerisinde bazen etkin bir konuma yükselirler. Pete'in Alice ile çalıştığı mekânda ilk karşılaştıkları sahne bu duruma örnek olarak verilebilir. Alice'in Dick Laurend ile Pete'in iş yerine gelişi, arabadan inişi sırasında Pete'e baştan çıkarıcı bakışı ve sonrası gelişmeler bu yaklaşımı destekleyen unsurlardır. Alice, adeta Fred'in eşi Renee'nin bir başka halidir. Baştan çıkarıcı tavrıyla bir sarışın femme fatale' dir.

Gelişen süreçle birlikte baştan çıkarıcı tavırlar sergileyen Alice, Pete'i yemeğe davet eder. Kadının erkeği yemeğe davet etmesi, geleneksel kadın imgesini dışında bir durumdur. $\mathrm{Bu}$ tavır moderniteyle birlikte yeniden şekillenmiş olan kadının toplum içerisindeki duruşuna bir vurgudur. Kadının edilgen alandan, kendine yer açarak daha etkin bir konuma geçmiştir. Bu etkinlikten dolayı kendisini sergilemekten de çekinmez. Ancak diğer taraftan bakıldığında ise çekici ve güzel olan arzu nesnesi bir kadın olarak görülebilir.

Kadın ile erkek karakter (Pete) arasında duran baba figürünü (Dick Laurent) temsil eden bir engelin olmasıdır. Bu engel, David Lynch filmlerinin en önemli temalardan birini oluşturan Odipal üçgenini tamamlamasıdır.

Tutkulu bir birliktelik yaşamaya başlayan Pete ve Alice, sık sık bir araya geldikleri görülmektedir. Bu buluşmalar Pete’te bir bağımlığa dönüşmüştür. Alice'in perden yansıyış hali bazen Renee'i anımsatır. Bu durum Alice ile Renee arasındaki geçirgenliği göstermek adına yapilmaktadir.

Pete, Alice'le buluşmak için Andy’nin evine gider. İçeri girdiğinde Alice’in başka biriyle yakınlaştığını görür. Barın arkasına saklanan Pete, Andy’nin bir şeyler almak için aşağıya indiğinde, eline geçirdiği cisimle Andy’e vurur. Andy cansız bir şekilde yatmaktadır. Kurbanın başında bekleyen Pete'nin bakış üzerinden Alice'in ekrana yansıyan görüntüsü görülmektedir. Yukardan olayın gerçekleştiği yere Alice gelir. Alice, Pete'nin yaptığından memnun gibi görünmektedir. Bu sırada bir anda ayağa kalkan Andy, Pete'e saldırır. Ancak Pete buna sert bir karşılık vererek ölümüne neden olur. Andy’nin yerde cansız ve her tarafı kan içinde yatması Lynch filmlerinde aktarılan bir sahnedir. Alice bu durumu soğukkanlılıkla 
karşılamıştır. Bir ara Peta'in gözü salondaki fotoğraflara ilişir. Bu fotoğraflar Eddy, Renee ve Alice birliktedir. Renee ve Alice yan yana gelmiştir. Pete, fotoğraflara bakar ve Alice fotoğraftakinin o olup olmadığını sorar. Fotoğraftaki sarışın olanı gösterir ve o olduğunu belirtir. Bu durum gerçek olanla, hayali bir araya getirerek çarpıştırmasıdır.

\subsection{Filmde Zaman ve Mekânın Sunumu}

Postmodern sinemanın temel özelliklerinden biri kullanılan zaman ve mekânın değişiklik gösterebilen yapısıdır. Bu yapı içerisinde nostaljik yapı ve pastiş unsurları kullanılmasıyla birlikte anlatıda değişimler olabilmektedir. Çünkü postmodernist anlatıya göre geçmiş ile yaşanan zaman arasında kesin bir ayırım söz konusu değildir. Başka bir ifadeyle anlatı yapısı içerisinde aktarılan parçalanmış durum, zaman ve mekân unsurlarının neden sonuç ilişkisi içerisinde ilerlemesini ortadan kaldırmaktadır. Bundan dolayı bütünsel bir zaman ve mekândan söz etmek olası değildir ve bunun üzerinden kurulacak olay örgüsü içinde zaman ve mekânın bütünsellik içerisinden aktarımını beklemekte mümkün olamamaktadır (Şaylan, 2016: 97). Zamanın anlatıda ortaya koyduğu belirsizlik ile mekânın bilinenin dışında bir yapı içermesi film parçalı bir anlatı ve birbirinin içine geçmiş bir yapıyı oluşturmaktadır. Bu doğrultuda çalışma konusu olan Kayıp Otoban filmine bakıldığında, zaman ve mekân arasındaki engellerin kalktığı, anlatı yapısındaki zamana uygunluk içermeyen unsurların var olduğu görülmektedir.

Filmde kullanılan mekanlar açısından değerlendirildiğinde, filmin çekildiği mekanların tam olarak neresi olduğu yönünde bir belirsizlik söz konusudur. Ancak filmin bir sahnesi olan, Eddy ve Pete'in dolaştıkları yolun Hollywood tepelerinden şehre doğru ilerleyen yer olabileceği yönünde fikir yürütülebilir. Bunu destekleyen bir başka unsur ise çöle çok yakın olmasıdır.

Filmde kullanılan mekanlardan biri de Fred ve Renee'in yaşadıkları evdir. Bu evin üst katı gerçek bir mekândan çok, adeta bir rüya gerçekliği gibidir. Filmde Pete'in 25 numaralı bir kapıdan geçip 26 numaralı kapımın önüne gelip durduğu görülmektedir. Bu aktarım aynı zamanda David Lyinch'in önceki filmlerinden olan Eraserhead filminin karakterlerinden Henry'nin kapı numarasıdır (Zizek, 2002: 148). Bu yapı içerisinde postmodern anti kahramanı olan Fred'in yaşadığı evren yıkıcı bir ruhsal enerji sahiptir. Bu atmosfer içerisinde olay örgüsü gerçeğin fantastikleştirilerek, mazoşist eylemlerin bilinmezliklerle dolu evreniyle izleyiciye aktarilır. 


\section{SONUÇ VE TARTIŞMA}

Çalışma konusu olan David Lynch'in Kayıp Otoban (Lost Highway) filmi gerek biçimsel ve gerekse de karmaşık anlatı yapısıyla birlikte belirsizlikler üzerine kurulan bir atmosferinde üzerinden ilerlemektedir. Paronaya, gizem ve cinayetin birlikte anlatısını aktaran film, istenenin her zaman kontrol altında tutulamayacağı üzerinde durarak izleyiciyi bu tekinsiz ortam içerisine sürüklemektedir.

Neoformalist yaklaşımın'e göre film anlatısının her bileşeni, seyircinin izlediği bütünsel modelin bir parçasıdır. Dolayısıyla konu, soyut düşünceler ve anlam gibi içerik olarak görülen birçok unsur, sanat yapıtının birbiri ile ilişkili bütünsel sistemine yani biçime dâhildir. Bu bağlamda bakıldığında, David Lynch'in film anlatıları sinemanın, fantezi, düş ve film karakterlerinin filmi izleyenlerin yarattığı kolektif imgelemin ve hafiza yoluyla oluşturulan gerçekliğe sırtını yaslayan bir gerçeklikten hareket eder.

Çalışma konusu olan Kayıp Otoban filmin anlatı yapısına bu doğrultuda bakıldığında yönetmenin önceki filmlerde kullandığı yaklaşıma ek olarak olay örgüsü üzerinden anlatısını gerçekleştirdiği görülmektedir. Film karakterleri üzerinde yaşanan değişim ve zaman zaman birbirlerini tamamlayan, aynı zamanda çatışmaya da dönüşen bir anlatı söz konusudur. Bu anlatı birbiriyle iç içe geçmiş, Fred ve Pete'nin olduğu iki ayrı anlatı üzerinden ilerlemektedir. Bu anlatılardan ilki, hikâyenin başladığı yerde son bulması, ikincisi ise karakterin benzer özellikler gösteren iki kadın, ya da görsel değişim yaşamış olan bir kadın üzerinden ilerlemektedir.

Kayıp Otoban filminin ilk düzlemi, sorunlu ve mutsuz olan karakterin şizofren bir çıkışla cevap vermesi üzerinden ilerlemektedir. Örneğin filmin ana karakterlerinden olan Fred, karısı (Renee) hakkında öğrendikleri sonrası durumu kabullenmek yerine kafasında fantazj üretmesi verilebilir. Film fantazinin oluşturduğu bilinmezlik içerisinde çırpınan bir adamın iç dünyasını yansıtmakla birlikte, iç güdülerin merkezine doğru yapılan yolculuğa dönüşmektedir. Bununla birlikte filmin ikinci düzlemi ise, yönetmenin önceki filmlerinde de kullandığı kötü, bilinmezlik ve kabusa doğru yol alınmasıdır. Bu yolculuğunda Fred'in sığındığı ikinci kimliği olan Pete ile yeni bir bilinmezlik ortamına girmektedir. Filmin anlatısında ilk başlarda var olan yabancılaşma üzerinden ilerlesede, devamında farklı bir yapı oluşmaktadır. Bu yapı içerisinde iletişimsizlik, özel hayata ilişkin sorunlar, güvensizlik ve yalanlar vardır.

Filmde öne çıkan bir başka husus, zihinde oluşturulan fantezi de bile çıkışsızlık, buna çözüm üretememe durumudur. Bununla birlikte filmde iki farklı cinsel edim yaşanmakta 
olduğu görülmektedir. Bunlardan birincisi Fred ve Renee arasındaki soğuk ve birbirlerine yabancılaşmış bir ilişkinin bulunması, ikincisi ise Pete ile Alice arasındaki tutkulu aşktır. Ancak bu her iki ilişkide de erkeğin başarısızlığıyla sonuçlanmaktadır. Bu durum karakterlerin kendilerini güçlü kılan odipal üçgenin parametreleri yeniden oluşturulduğu bir sarmala dönüşür. Alice'in (Patricia Arquette) Pete'e "bana asla sahip olamayacaksın” dedikten sonra gerçekliğe geri dönüş yapılır ve Pete, Fred'e dönüşür. Başka bir ifadeyle fantazinin başarısızlığıyla birlikte bu gerçekleşir. Bundan dolayı kurulan fantazinin başarısızlığıyla birlikte Pete, Fred'e geri dönüştürülür.

Postmodern sinema anlatısında kullanılan yöntemlerden biri de anlatı dilinde doğrusallığın kullanılmaması ve düzensizliği kendisine yöntem olarak benimsemesidir. Filmde bu duruma örnek verilebilecek sahne, filmin başında gösterilmektedir. Bu sahnede, interkomda “Dick Laurent öldü” sesi duyulur. Bu söz gerek zamansal gerekse de anlamsal düzlemde klasik anlatının dışındadır. Bundan dolayı sözün izleyici üzerinde etki seviyesi düşüktür. Başka bir ifadeyle herhangi bir anlam çağrıştırmamaktadır. Çünkü olay aktarımı neden sonuç ilişkisi üzerinden ilerlememektedir. Bu duruma verilebilecek bir başka örnek ise Fred'in hücresindeki dönüşüm anında yaşanmaktadır. Bulanık bir şekilde seçilen slüet görüntü, aslında çölde araba farlarının Alice'nin görüntüsüne yansımasıdır.

Filmin olay örgüsü içerisinde Fred'in gördüğü rüya, kaset ve cinayet üç düzlemin birbiri içerisine girmesiyle ilerler. Gerçekleşecek olan cinayet eyleminden önce görüntüsü verilir. Varlık ve bilinç birbirinden ayrılmıştır. Film izleyicisinin buradan yeni bir gerçeklik kurma girişiminin başarılı olma olasılığı fazla olası değildir. Bu durum Quentin Tarantino'nun filmlerinde kullanılan "sıra bozumuna” denk bir aktarımdır. Film olay örgüsü içerisinde önce cevap verilip sonra soru sıralama durumuna geçilir. Quentin Tarantino'nun Rezarvuar Köpekleri filminde hangarda yerde vurulmuş olarak gösterilen karakterin yaşadıkları gibi, çalışma konusu olan Kayıp Otoban filminde de benzer aktarımlarla düzen bozma gerçekleştirilmektedir.

Filmin anlatı dilindeki bir başka aktarım ise karakterlerin belirsizliğidir. Karakteler üzerinde yaratılan bu belirsizlik, filmin anlatısında doğrular yaratma ve bunu aktarma gibi bir kaygı taşımamasından kaynaklanmaktadır. Bundan dolayı film karakterlerinin tutum ve davranışlarında belirsizlik vardır. Örneğin filmin kadın karakterlerinden olan Alice veya Renee'nin gerçekte kim oldukların yönelik bir belirsizlik söz konusudur. Fred'in eşi olan Renee'nin ölümü belirsizliklerle örülü bir aktarımla yapılır. Aynı belirsizlik erkek 
karakterlerinin anlatı aktarımlarında da mevcuttur. Kayıp Otoban filminin anlatısında yaratılan belirsizlik bilinçli bir tasarımın ürünüdür. Türe özgü ve Davit Lyinch'in anlam yaratma becerisiyle ilgili olduğu söylenebilir.

Sonuç olarak Kayıp Otoban (Lost Highway) filmi anlatısında cinselliği, şiddeti ödipal yapının öne çıktığı bir yapım olduğu söylenebilir. David Lynch'in film anlatı dilinde karakterlerin izledikleri yolu, bedenen fiziksel engellerinden kurtulmaları gibi aktarımlarla anlam yaratma unsurlarından olan 1şı̆̆ı başarılı bir şekilde kullanarak karakterlerin sanki hiçliğin orta yerinden çıkıp gelmiş gibi yansıtmaktadır. Bunu da Freud'un insan motivasyonunun temel döngüsü olarak belirlediği hayat döngüsünün sürmesi için cinsellik ve onun benliğin oluşumundaki etkisi karakterlerin iç dünyası üzerinden aranmaktadır. Filmin sembolik imgelemler, metaforlar ve iç içe geçen hikayeler açısından zengin bir içeriğe sahip olan postmodernist bir film özelliği taşıdığı söylenebilir. Film anlatı yapısı içerisinde odipal evrene geçiş, ise Fred'in karısını öldürmesinden sonraki süreçte başlamaktadır. Bu süreçte Fred'in başka birine dönüşmesi, Renee'nin bir femme fatale bedende var olması, Alice ve çiftin arasına giren karakter de Eddy üzerinden gerçekleşmektedir.

\section{REFERENCES / KAYNAKLAR}

Abisel, N. \& Eryılmaz, T. (1980). Sinemanın çağdaşlaşması: Yeni gerçekçilik, yeni dalga. İçinde, Sinema araştırmaları. İstanbul: Derin Yayınları.

Andrew, G. (2004). Stranger than paradise: Maverick film makers in recent American cinema. London: Prion Books.

Appleby, C. (1996). Knowledge and postmodernism in historical perspective routledge. Great Britain: Psychology Press.

Araz, T. (1999). Coming to terms with a postmodern world: Donald Bhartelme's dissident stance in show white and other storles. İstanbul: Çantay Kitabevi.

Ashley, D. (1997). History without a subject -the postmodern condition westview. United States of America, Colarado: Press.

Baudrillard, J. (2012). Sanat komplosu: Yeni sanat düzeni ve çă̆daş estetik (E. Gen \& I. Ergüden, Çev.; A. Artun, Ed.). İstanbul: İletişim Yayınları.

Baudrillard, J. (2014). Simülakrlar ve simülasyon. Ankara: Doğu Batı Yayınları.

Bertens, H. (1995). The idea of the postmodern: A history. USA and Canada: Routledge.

Best, S. \& Kelner, D. (1998). Postmodern Teori (M. Küçük, Çev.). İstanbul: Ayrıntı Yayınları. 
Brown, D. H. (1995). Postmodern representations. University of Illincis Press: Urbana and Chicago.

Büyükdüvenci, S. \& Öztürk, S. R. (1997). Postmodernizm ve sinema (1. Baskl). Ankara: Bilim ve Sanat Yayınları. Connor, S. (2001). Postmodernist kültür (1. Baskl) (D. Şahiner, Çev.). İstanbul: YKY.

Danto, A. C. (2010). Sanatın sonundan sonra (Zeynep Demirsü, Çev.). İstanbul: Ayrıntı Yayınları.

Dear, M. (1993). Multiculturalism difference and postmodernism (L. G. Clark, D. K. Forbes \& R. Francis, Eds.). Malaysia: Logman Cheshire.

Eaglaton, T. (2015). Postmodernizmin yanılsamaları (M. Küçük, Çev.). İstanbul: Ayrıntı Yayınları.

Featherstone, M. (1996). Postmodernizm ve tüketim kültürü (M. Küçük, Çev.). İstanbul: Ayrıntı Yayınları.

Foster, H. (2009). Gerçeğin geri dönüşü yüzyılın sonunda avangard (E. Hoşsucu, Çev.) İstanbul: Ayrıntı Yayınları. Giddens, A. (1998). Modernliğin sonuçları (2. Basım) (E. Kuşdil, Çev.). İstanbul: Ayrıntı Yayınları

Harvey, D. (2014). Postmodernliğin durumu (2. Baskı) (S. Savran, Çev.). İstanbul: Metis Yayınları.

Jameson, F. (1994). Postmodernizm ya da geç kapitalizmin kültürel mantığl (N. Plümer, Çev.). İstanbul: Y.K.Y.

Lyotard, J. F. (1990). Postmodern nedir sorusuna cevap. İçinde N. Zekâ (Edited by), Postmodernizm. İstanbul: Kiyı Yayınları.

Lyotard, J. F. (2014). Postmodern durum (Dr. İ. Birkan, Çev.). Ankara: Bilgesu Yayıncılık.

Murphy, J. (2000). Postmodern sosyal analiz ve postmodern eleştiri (H. Arslan, Çev.). İstanbul: Paradigma Yayınları.

Özdemir, S. T. (2003). Kara filmler: Neo noir'den future noir'a. İstanbul: Altıkırkbeş Yayınları.

Richter, H. (1998). Activism, modernism and the avangt-garde (S. C. Foster, Edited by). London: The MIT Press. Sarup, M. (2010). Post-yapısalcılık ve postmodernizm (A. Güçlü, Çev.). İstanbul: Kırk Gece Yayınlar.

Sennett, R. (2019). Karakter aşınmast/yeni kapitalizmde işin kişilik üzerindeki etkileri (B. Yıldırım, Çev.). İstanbul: Ayrıntı Yayınları.

Sim, S. (1999). The routledge critical dictionary of postmodern thought. New York: Routledge.

Shinner, L. (2010). Sanatın icadı (İ. Türkmen, Çev.). İstanbul: Ayrıntı Yayınları.

Smith, H. (2003). Beyond the postmodern mind: The place of meaning in a global civilization. Paperback - July

Şaylan, G. (2016). Postmodernizm. Ankara: İmge Kitapevi.

Urry, J. (1999). Mekânları tüketmek (R. Öğdül, Çev.). İstanbul: Ayrıntı Yayınları

Vattimo, G. (1992). The transparent society (D. Webb, Trans.). Cambridge: Polity Pres.

Y1lmaz, M. (2012). Sanatın günceli güncelin sanatı. Ankara: Ütopya Yayınevi.

Zizek, S. (2001). David Lynch ya da Gülünç Yücenin sanatı. Gülünç Yüce'nin sanatı: David Lynch'in kayıp otoban'ı üzerine (S. Gürses, Çev.) İstanbul: Om Yayınları.

Zizek, S. (2002). Kırılgan temas (T. Birkan, Çev.). İstanbul: Metis Yayınları. 